\title{
Mechanism of ATP-Induced Local and Conducted Vasomotor Responses in Isolated Rat Cerebral Penetrating Arterioles
}

\author{
Hans H. Dietrich ${ }^{a, b}$ Tetsuyoshi Horiuchia,d Chuanxi Xiang ${ }^{a}$ Kazuhiro Hongo $^{d}$ \\ J. Russell Falck ${ }^{c}$ Ralph G. Dacey, Jr. ${ }^{a}$ \\ a Department of Neurosurgery, and ${ }^{\mathrm{b}}$ Hope Center, Washington University School of Medicine, St. Louis, Mo.; \\ 'Department of Biochemistry, University of Texas Southwestern Medical Center, Dallas, Tex., USA; \\ ${ }^{\mathrm{d}}$ Department of Neurosurgery, Shinshu University School of Medicine, Matsumoto, Japan
}

\section{Key Words}

Adenosine $5^{\prime}$-triphosphate $\cdot$ Cerebrovascular circulation $\cdot$

Microcirculation - Cytochrome $\mathrm{P} 450 \cdot \mathrm{P}_{2}$ receptors .

Potassium channels

\begin{abstract}
Background: Adenosine triphosphate (ATP), a potent vascular regulator in the cerebral circulation, initiates conducted vasomotor responses which may be impaired after pathological insults. We analyzed the mechanism of ATP-induced local vasomotor responses and their effect on conducted vasomotor responses in rat cerebral penetrating arterioles. Methods: Arterioles were cannulated and their internal diameter monitored. Vasomotor responses to ATP were observed in the presence or absence of inhibitors, or after endothelial impairment. Smooth muscle membrane potentials were measured in some vessels. Results: Microapplication of ATP produced a biphasic response (constriction followed by dilation), which resulted in conducted dilation preceded by a membrane hyperpolarization. $\alpha, \beta$-methylene-ATP or pyridoxal phosphate-6-azophenyl-2',4'-disulfonic acid (PPADS) blunted the ATP-mediated constriction and enhanced local and conducted dilation. $\mathrm{N}^{\omega}$-monomethyl-L-arginine, endothelial impairment and $\mathrm{N}$-methylsulfonyl-6-(2-
\end{abstract}

propargyloxyphenyl) hexanamide (MS-PPOH) reduced the local dilation caused by ATP. The conducted dilation was attenuated by MS-PPOH and endothelial impairment, but not $\mathrm{N}^{\omega}{ }^{\omega}$-monomethyl-L-arginine or indomethacin. Conclusion: ATP-induced conducted dilation is preceded by membrane hyperpolarization. Local ATP induces initial local constriction via smooth-muscle $P_{2 \times 1}$ and subsequent dilation via endothelial $P_{2 Y}$ receptors. Nitric oxide, cytochrome P450 metabolites, and intermediate and large conductance $\mathrm{K}_{\mathrm{Ca}}$ channels mediate dilation caused by ATP. ATP-induced conducted dilation is dependent upon both the endothelium and cytochrome P450 metabolites.

Copyright $\odot 2008$ S. Karger AG, Basel

\section{Introduction}

Cerebral penetrating arterioles are precapillary microvessels that regulate the distribution of blood into the capillary cortical bed and which may contribute up to $23 \%$ of total cerebrovascular resistance [1]. The penetrating arteriole running in the Virchow-Robin space may serve as a means by which neural activity and synaptic transmission can be metabolically coupled with local cerebral blood flow [2]. Neuronal cerebral stimulation re-

\section{KARGER}

๑ 2008 S. Karger AG, Basel

Fax +41613061234

E-Mail karger@karger.ch

www.karger.com
Accessible online at:

www.karger.com/jvr
Dr. Hans H. Dietrich

Department of Neurosurgery, Washington University School of Medicine

Box 8057, 660 South Euclid Avenue

St. Louis, MO 63110 (USA)

Tel. +1 314362 3648, Fax +1 314362 2107, E-Mail dietrichh@nsurg.wustl.edu 
leases adenosine triphosphate (ATP), a potent vasoactive agonist in the cerebral circulation [3-6]. Such ATP, as well as ATP released from other cerebral sources, including perivascular nerves, parenchymal tissue, red blood cells and platelets [see 4] could cause local vasomotor responses. Since communication of this local agonist-induced vasoactivity to the proximal supply vessels is required to appropriately adjust local blood flow, the local response must initiate a response which is spread along the vessel; that is, the response must be conducted [7].

In rat penetrating arterioles, locally applied ATP elicits a biphasic response consisting of an initial transient constriction followed by a dilation which is subsequently conducted along the vessel wall [8-10]. In hamster retractor muscle, extraluminal microapplied ATP caused conducted arteriolar vasoconstriction, while intraluminal ATP caused conducted vasodilation [11]. In hamster cheek pouch arterioles, Duza and Sarelius [12] observed that microapplied ATP caused a local vasoconstriction followed by a conducted vasodilation, a response similar to that observed in cerebral vessels. They determined that the local transient constriction was mediated by $\mathrm{P}_{2 \mathrm{x}}$ receptors with the subsequent dilation via $\mathrm{P}_{1}$ receptors with their agonist, the ATP hydrolysis product adenosine [12]. In rat penetrating arterioles, we found that extraluminal ATP stimulates smooth muscle $\mathrm{P}_{2 \mathrm{X} 1}$ and endothelial $\mathrm{P}_{2 \mathrm{Y} 1}$ and $\mathrm{P}_{2 \mathrm{Y} 2}$ receptors [13]. The contribution of $\mathrm{P}_{2}$ receptors initiating conducted vasomotor responses in penetrating arterioles has not been described.

Inhibition of nitric oxide synthase (NOS) resulted in diminished conducted dilation to intraluminal ATP and enhanced conducted constriction in hamster retractor muscle arterioles, indicating a possible contribution of NO to the conducted vasomotor response in these arterioles [11]. Although the contribution of endothelium-derived hyperpolarizing factor (EDHF) to ATP-induced conduction has not been studied, Hoepfl [14] did report that in hamster cremaster arterioles, the response to locally applied acetylcholine was mediated via EDHF and not by NO. In rat penetrating arterioles, $\mathrm{P}_{2 \mathrm{Y}}$ receptor stimulation releases $\mathrm{NO}$ and possibly EDHF, but not prostanoids [13]. The contribution of NO or EDHF to the conducted response has not been studied in penetrating arterioles.

The underlying mechanism of conducted vasomotor responses is the spread of a local membrane potential change along the vessel via electromechanical coupling. Dora et al. [15] found that in hamster cheek pouch arterioles, local acetylcholine caused a hyperpolarization followed by a dilation, and a subsequent conducted hyper- polarization preceded a conducted dilation. A role for a similar conducted membrane potential change in the ATP-induced conduction has not been studied.

The goal of this study was to examine if electromechanical coupling underlies the observed conducted vasomotor responses to ATP in rat cerebral penetrating arterioles. Further, we wanted to determine the contribution of NOS, cyclooxygenase and cytochrome P450 inhibition on local ATP-receptor-mediated smooth-muscle and endothelial mechanisms involved in conducted vasomotor responses to topical microapplication of ATP in cerebral penetrating arterioles in vitro. In additional experiments, we also examined the possible contribution of $\mathrm{K}_{\mathrm{Ca}}$ inhibition on the response to extraluminal ATP stimulation, since cytochrome P450-produced epoxyeicosatrienoic acids (EETs) induce vasodilation via stimulation of calcium-activated potassium channels $\left(\mathrm{K}_{\mathrm{Ca}}\right)$ [16]. We also examined the possible contribution of ectoATPases to extraluminal ATP-induced vasomotor responses.

\section{Materials and Methods}

Isolation and Cannulation of Penetrating Arterioles

All procedures were approved by the Washington University Advisory Committee for Animal Resources. Male Sprague-Dawley rats (350-450 g, Harlan, Indianapolis, Ind., USA) were anesthetized with pentobarbital sodium (65 $\mathrm{mg} / \mathrm{kg}$ intraperitoneally) and sacrificed. The cerebral penetrating arterioles were excised from the middle cerebral artery. Arterioles were transferred to an organ bath (volume $2.5 \mathrm{ml}$ ) mounted on the stage of an inverted video microscope (Diaphot, Nikon, Melville, N.Y., USA) and cannulated with glass micropipettes. No intraluminal flow was applied and the transmural pressure was set at $60 \mathrm{~mm} \mathrm{Hg}$ and continuously monitored. We observed the internal diameter of the vessels using a computerized diameter-tracking system (Diamtrak, Montech Pty. Ltd., Australia).

The arterioles were continuously superfused with a physiological saline solution $\left(37.5^{\circ} \mathrm{C}, \mathrm{pH} 7.3\right)$ of the following composition (in mmol/l): $144 \mathrm{NaCl}, 3.0 \mathrm{KCl}, 2.5 \mathrm{CaCl}_{2}, 1.4 \mathrm{MgSO}_{4}, 2.0$ pyruvate, 5.0 glucose, 0.02 ethylenediaminetetraacetic acid, $2.03-(\mathrm{N}-$ morpholino) propanesulfonic acid (MOPS) and $1.21 \mathrm{NaH}_{2} \mathrm{PO}_{4}$. After equilibration, the vessels developed spontaneous tone and we confirmed their viability by changing the extraluminal $\mathrm{pH}$ from 7.3 to 6.8 and from 7.3 to 7.65 . Vessels with poor tone $(<20 \%$ decrease from the maximum diameter) or poor response to $\mathrm{pH}$ $(<15 \%$ change in diameter after $\mathrm{pH}$ alteration) were excluded.

Local Microstimulation by ATP

For topical microapplication, ATP $(10 \mathrm{mmol} / \mathrm{l}$ in distilled water) was backfilled into borosilicate glass micropipettes (World Precision Instruments, Sarasota, Fla., USA) and pulled (using a Model P-87, Sutter Instruments, Novato, Calif., USA) to a tip with 1.5-2.0 $\mu \mathrm{m}$ inner diameter. The micropipette was positioned near the arteriolar wall (within $20 \mu \mathrm{m}$ ) and ATP was applied by pres- 
sure ejection (Picospritzer II, General Valve, Fairfield, N.J., USA; $50-450 \mathrm{~ms}$ in 100 -ms steps at 20 psi using $100 \%$ nitrogen gas) resulting in ejected volumes of 50-500 pl onto the abluminal surface of the vessel. These stimulation parameters provided a vasomotor response similar to that observed previously for ATP applied globally into the tissue bath with a $450-\mathrm{ms}$ pulse of ATP equivalent to a global concentration of $100 \mu \mathrm{mol} / \mathrm{l}$ ATP $[8,9]$. Initially, responses were observed at the site of stimulation (local). The micropipette was then positioned at the opposite end (remote site) of the vessel and the same stimulation was used, enabling observation of conducted responses. The ejected agonist did not spread further than $70 \mu \mathrm{m}$ from the tip at the highest pulse duration, which was consistent with previous observations. Ejections of the control solution had no impact on vessel diameter [8].

\section{Measurement of Membrane Potential}

Membrane potential measurements of vascular smooth muscle were obtained as described earlier [17]. Intracellular electrodes were backfilled with $4 \mathrm{~mol} / \mathrm{l}$ of potassium acetate and attached to a direct current amplifier (WPI, input impedance of $300 \mathrm{M} \Omega$ ) with an $\mathrm{Ag} / \mathrm{AgCl}$ reference electrode. The amplifier output and vessel diameter were recorded simultaneously. Smooth-muscle cells were identified according to their location (they were the cells next to the clearly visible endothelium). To facilitate electrode penetration we used a piezo stepper (Model 5172, Eppendorf, Hamburg, Germany) and penetration was considered successful when we observed a sudden change of membrane potential of at least $-25 \mathrm{mV}$, with removal of the electrode inducing a return of the membrane potential to baseline.

\section{Pharmacological Analysis of Vasomotor Responses to Local} ATP Stimulation

The vessel was stimulated locally and remotely in the presence or absence of globally applied inhibitors or after endothelial impairment. All drugs were obtained from Sigma Chemicals (St. Louis, Mo., USA). We used the following inhibitors to analyze the ATP-induced local and conducted responses: $1 \mu \mathrm{mol} / \mathrm{l} \alpha, \beta$-methylene-ATP $\left(\alpha, \beta\right.$-MetATP, a $\mathrm{P}_{2 \mathrm{X1}}$ receptor antagonist) and $3 \mu \mathrm{mol} / \mathrm{l}$ pyridoxal phosphate-6-azophenyl-2',4'-disulfonic acid (PPADS, a $\mathrm{P}_{2 \mathrm{X} 1}$ antagonist at this concentration) $[4,18] ; 100 \mu \mathrm{mol} / \mathrm{l}$ PPADS (a $\mathrm{P}_{2 \mathrm{X} 1}$ and $\mathrm{P}_{2 \mathrm{Y} 1}$ receptor antagonist at this concentration) $[4,18]$; $10 \mu \mathrm{mol} / 1 \mathrm{~N}^{\omega}$-monomethyl-L-arginine (L-NMMA, a NOS inhibitor), $10 \mu \mathrm{mol} / \mathrm{l}$ indomethacin (cyclooxygenase inhibitor), 1 $\mu \mathrm{mol} / \mathrm{l} \quad \mathrm{N}$-methylsulfonyl-6-(2-propargyloxyphenyl) hexanamide (MS-PPOH, inhibitor to specifically inhibit the production of EETs) [19]. Air emboli applied at $60 \mathrm{~mm} \mathrm{Hg}$ intraluminal pressure were used to functionally impair the endothelium without smooth-muscle damage [4].

\section{Calcium-Sensitive Potassium Channels and Extraluminally} Applied ATP

Calcium-sensitive potassium channels are activated by EETs [16], which may be released in response to ATP. To examine the contribution of $\mathrm{K}_{\mathrm{Ca}}$, we observed vasomotor responses to extraluminally applied ATP in the absence or presence of the following potassium channel inhibitors: 1-[(2-chlorophenyl)diphenylmethyl]-1H-pyrazole (TRAM-34, $0.1 \mu \mathrm{mol} / \mathrm{l}$ ) applied intraluminally to inhibit endothelial intermediate-conductance calcium-activated potassium channels $\left(\mathrm{IK}_{\mathrm{Ca}}\right)$ [20]. Extraluminally, we applied apamin $(0.1 \mu \mathrm{mol} / \mathrm{l})$ to specifically inhibit small-conductance po- tassium channels $\left(\mathrm{SK}_{\mathrm{Ca}}\right)$ [21] and iberiotoxin $(0.1 \mu \mathrm{mol} / \mathrm{l})$ to specifically inhibit large-conductance potassium channels $\left(\mathrm{BK}_{\mathrm{Ca}}\right)$ [20].

\section{Contribution of ATP Hydrolysis to Extraluminally Applied ATP}

Since ecto-ATPases can hydrolyze ATP to adenosine which could stimulate $P_{1}$ receptors [12], and since adenosine receptors are present on the smooth-muscle cells of rat penetrating arterioles [22, 23], we used $1 \mu \mathrm{mol} / 1$ suramin to inhibit ecto-ATPases, thus reducing the production of adenosine [24].

\section{Statistics}

In this study, only one vessel was used from each animal. All data are presented as mean \pm SEM, with $n$ representing the number of observations. Statistics were conducted on absolute vessel diameters. Differences were considered significant at $\mathrm{p}<0.05$ and determined by repeated-measures analysis of variance (RANOVA) with the Student-Newman-Keuls test or paired Student's t test as post test, where appropriate. The data are presented as relative diameter change. Percentage relative vessel diameter $=\mathrm{D}_{\text {ATP }} /$ $D_{\text {tone }} \times 100$, where $D_{\text {tone }}$ is the baseline diameter of the vessel before the stimulation with ATP and $\mathrm{D}_{\mathrm{ATP}}$ is the diameter of the vessel after stimulation. If a treatment modified the tone diameter (e.g. air embolism or NOS inhibition), data are presented as percentage of the maximal diameter, to correct for the changed control diameter, and were calculated by the following formula: percentage of maximum dilation $=\left[\left(\mathrm{D}_{\mathrm{ATP}}-\mathrm{D}_{\text {tone }}\right) /\left(\mathrm{D}_{\max }-\mathrm{D}_{\text {tone }}\right)\right] \times$ 100 , where $D_{\max }$ is the maximum diameter of the vessel at $60 \mathrm{~mm}$ $\mathrm{Hg}$ before the development of spontaneous tone [3, 13].

\section{Results}

\section{Diameter and Membrane Potential Response to Local ATP Application}

The vessels used for membrane potential measurements had an average length of $1,240 \pm 230 \mu \mathrm{m}$, a maximum diameter of $59.3 \pm 1.3 \mu \mathrm{m}$ and a tone diameter of $44.8 \pm 1.1 \mu \mathrm{m}$, with a resting membrane potential of $-36.4 \pm 3.0 \mathrm{mV}(\mathrm{n}=6)$. Microapplication of ATP resulted in a brief local vasoconstriction followed by a vasodilation (fig. 1a). The conducted response was consistently a vasodilation (fig. 1b). This conducted vasodilation was preceded by a membrane hyperpolarization with stimulus-dependent increases in conducted dilation and membrane hyperpolarization, as shown in figure $1 \mathrm{c}$ and $\mathrm{d}$. For 450 -ms pulses, the average maximum hyperpolarization was $-16 \mathrm{mV}(72.5 \%)$ resulting in a significant $6.5 \mu \mathrm{m}$ (10\%) dilation at the remote site (fig. 1c). The remote site hyperpolarization was initiated $0.6 \pm 0.1 \mathrm{~s}$ after pulse application, preceding vessel dilation, which occurred at $1.7 \pm 0.1 \mathrm{~s}(\mathrm{p}<0.05)$, with both responses independent of pulse duration (data not shown). Occasionally, we observed a small yet insignificant depolarization with a 


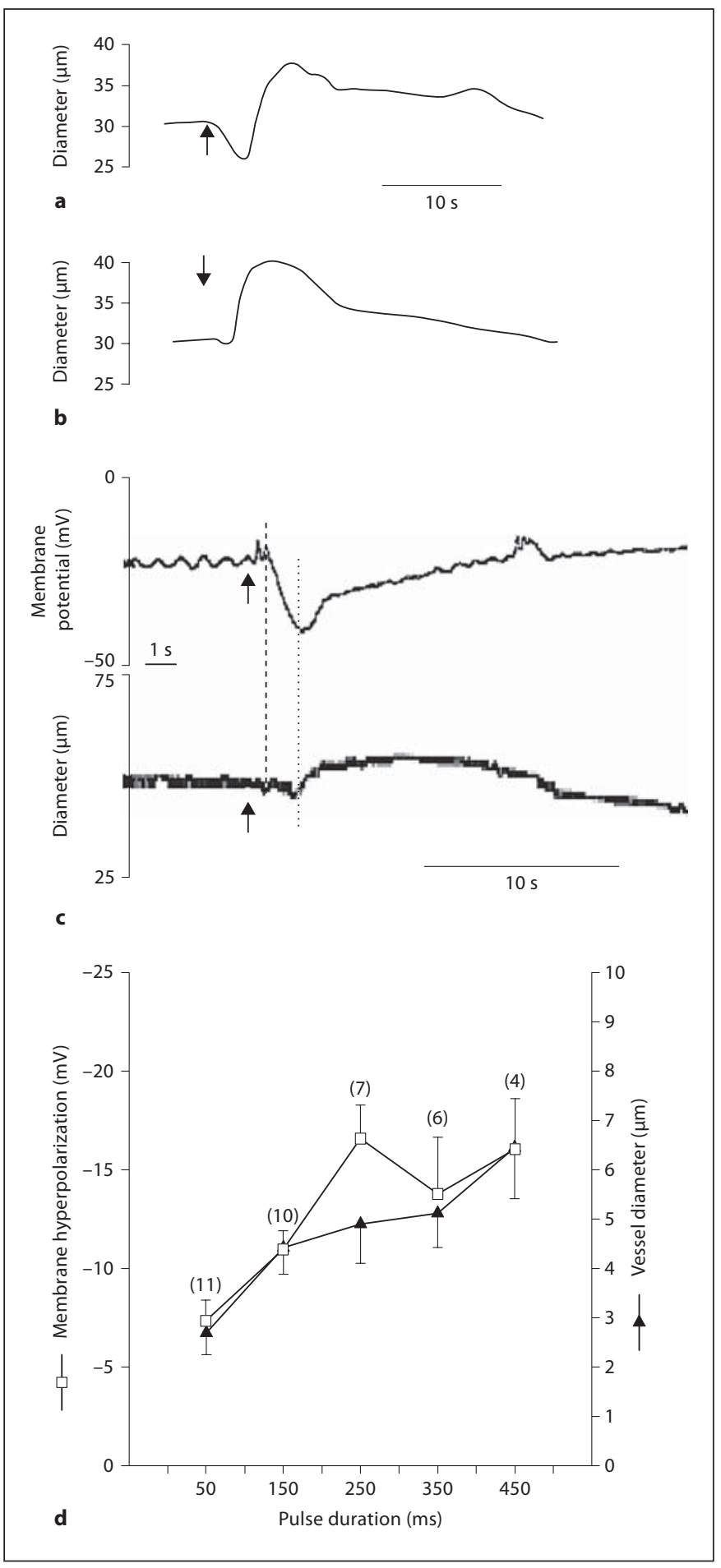

Fig. 1. Diameter traces of the local (a) and conducted (b) vasomotor response to microapplied ATP (arrows) with a transient local constriction (downstroke) followed by a dilation, with only a small conducted initial constriction but a strong conducted dilation (upstroke). c The simultaneous measurement of conducted vasomotor responses and membrane potential to microapplied subsequent small conducted vasoconstriction prior to the conducted hyperpolarization and dilation (data not shown).

\section{Evaluation of the ATP-Induced Vasomotor Responses to Purinoceptor Inhibition}

The vessels used for pharmacological evaluation of local and conducted vasomotor mechanisms had a tone diameter of $36.6 \pm 1.9 \mu \mathrm{m}$ and a length of $1,072 \pm 47 \mu \mathrm{m}$ $(\mathrm{n}=31)$. Microapplied ATP induced significant local transient constrictions and subsequent dilations. We consistently observed a conducted dilation, which was sometimes preceded by a small vasoconstriction.

Vessels treated with $\alpha, \beta$-MetATP had a maximum diameter of $53.8 \pm 5.8 \mu \mathrm{m}$ and a tone diameter of $35.1 \pm$ $5.7 \mu \mathrm{m}(\mathrm{n}=5) .1 \mu \mathrm{mol} / \mathrm{l} \alpha, \beta$-MetATP applied extraluminally transiently constricted the vessels via smooth muscle $\mathrm{P}_{2 \mathrm{X} 1}$ receptors with the vessels subsequently returning to their basal diameter due to $\mathrm{P}_{2 \mathrm{X} 1}$ receptor desensitization [4]. After this desensitization, subsequent ATP-induced local and conducted constrictions were significantly attenuated in the presence of $\alpha, \beta$-MetATP, while local and conducted dilations were greatly enhanced (fig. 2).

Vessels treated with PPADS had a maximum diameter of $45.9 \pm 4.0 \mu \mathrm{m}$ with a tone diameter of $35.8 \mu \mathrm{m}(\mathrm{n}=$ 7). PPADS ( 3 and $100 \mu \mathrm{mol} / \mathrm{l}$ ) had no effect on the control diameter (data not shown). $3 \mu \mathrm{mol} / \mathrm{l}$ PPADS (a $\mathrm{P}_{2 \times 1}$ receptor antagonist at this concentration) significantly blocked local transient constrictions to ATP, similar to the effect of $\alpha, \beta$-MetATP (fig. 3). The ATP-induced local and conducted dilation was potentiated by $3 \mu \mathrm{mol} / \mathrm{l}$ PPADS (fig. 3). Addition of $100 \mu \mathrm{mol} / \mathrm{l}$ PPADS ( $\mathrm{P}_{2 \mathrm{X} 1}$ and $\mathrm{P}_{2 \mathrm{Y} 1}$ receptor antagonists at this concentration) [18] further inhibited the local transient constriction, but had no additional effect on the conducted dilation (fig. 3).

Since ecto-ATPases on vascular cells can hydrolyze ATP to adenosine, which activates $P_{1}$ receptors causing vasodilation [12], we used suramin, which has been shown to reduce ecto-ATPase activity at micromolar concentra-

ATP (arrows) with the hyperpolarization (dashed line) preceding the dilation (dotted line). d Stimulus-dependent increase between conducted dilation and membrane hyperpolarization to increasing duration of ATP pulse. All data points were significantly different $(\mathrm{p}<0.05)$ from their respective prestimulation control (ANOVA). 


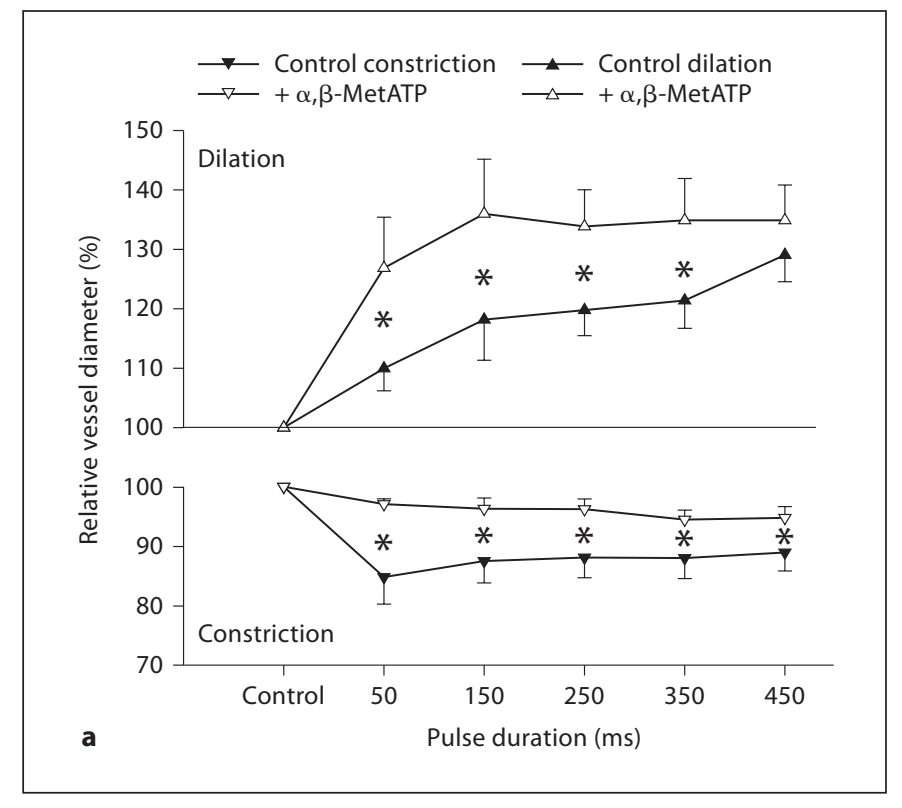

Fig. 2. Effect of $\alpha, \beta$-MetATP on ATP-induced responses. Desensitizing $\mathrm{P}_{2 \mathrm{X} 1}$ receptor with $\alpha, \beta$-MetATP $(1 \mu \mathrm{mol} / \mathrm{l})$ significantly reduces local (a) and conducted (b) initial vasoconstriction and enhances local and conducted dilation. This indicates that $\mathrm{P}_{2 \mathrm{X} 1}$

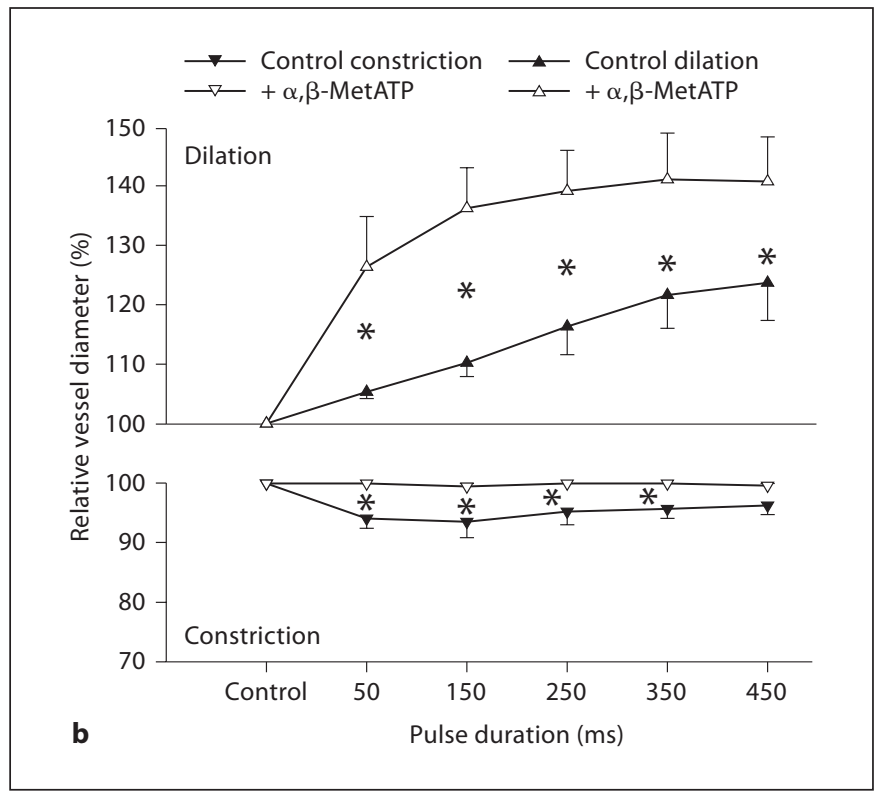

receptors cause the initial transient vasoconstriction which attenuates $\mathrm{P}_{2 \mathrm{Y}}$-receptor-induced dilation. $\mathrm{n}=5$. ${ }^{*} \mathrm{p}<0.05$ (RANOVA) between control and after desensitization with $\alpha, \beta$ MetATP.

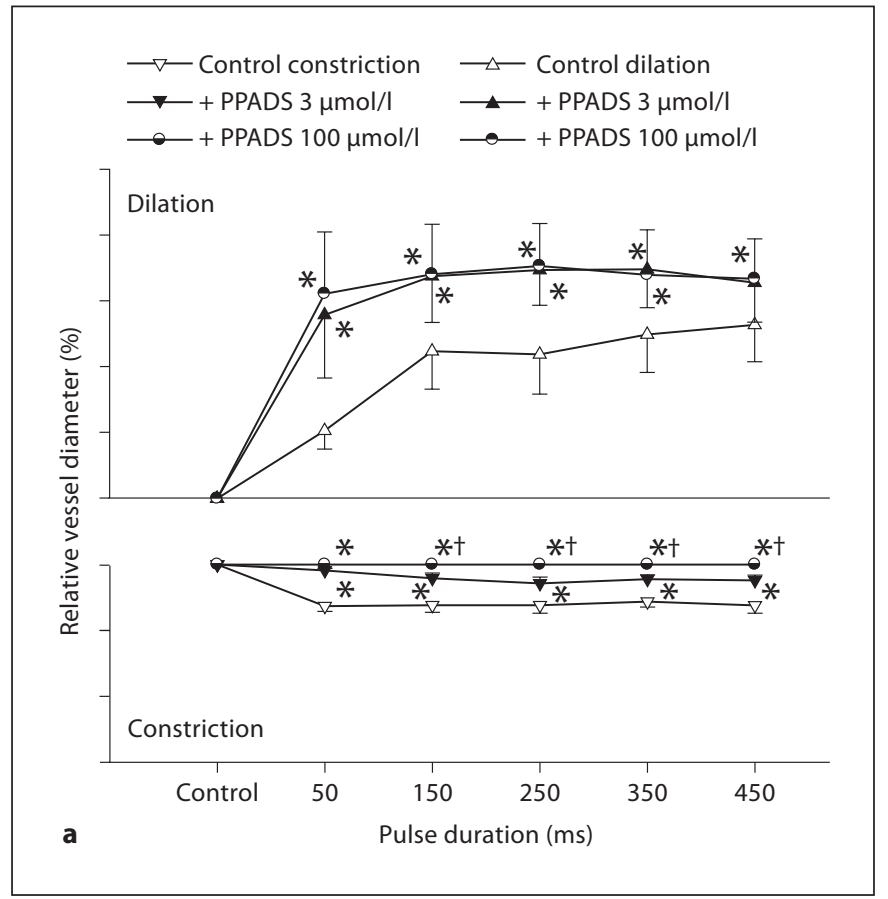

Fig. 3. Effect of PPADS on ATP-induced responses. Inhibiting $\mathrm{P}_{2 \mathrm{X} 1}$ with PPADS $(3 \mu \mathrm{mol} / \mathrm{l})$ significantly reduces local (a) and conducted (b) initial vasoconstriction and greatly enhances local and conducted dilation similarly to $\alpha, \beta$-MetATP (fig. 2). Inhibiting all $\mathrm{P}_{2}$ receptors except $\mathrm{P}_{2 \mathrm{Y} 2}$ with $100 \mu \mathrm{mol} / \mathrm{l}$ PPADS further

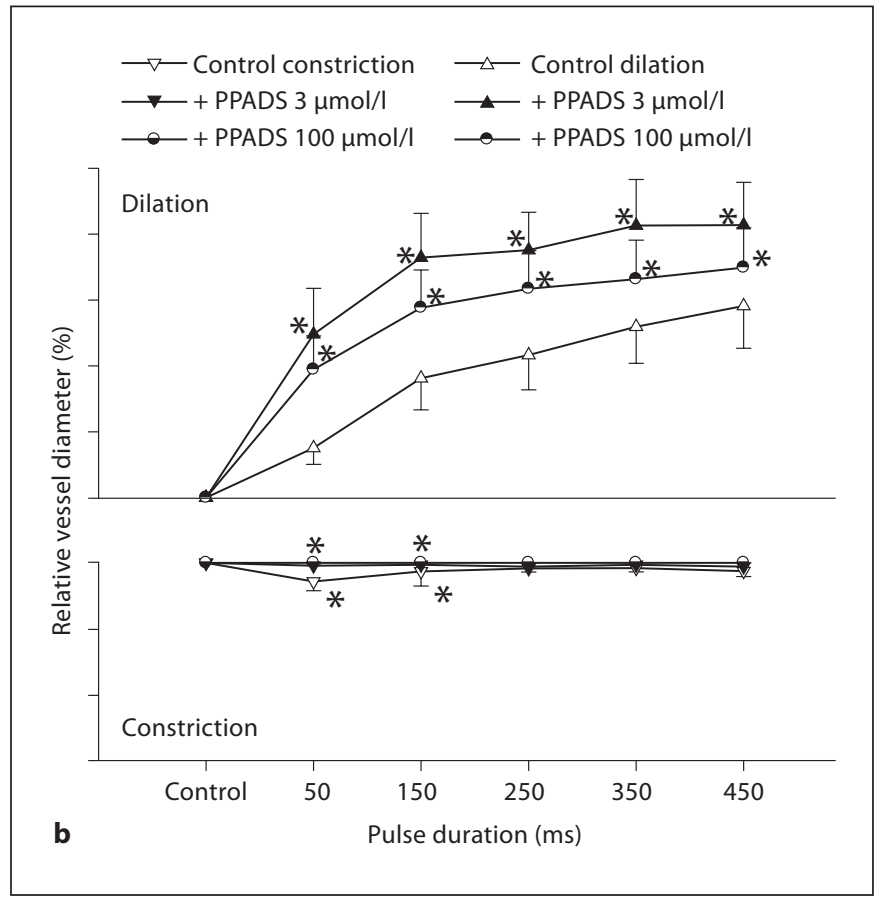

reduces local transient constriction, but has no further effect on local or conducted dilation, indicating that ATP stimulates $\mathrm{P}_{2 \mathrm{Y} 2}$ receptors to cause dilation. $\mathrm{n}=7$. $^{*} \mathrm{p}<0.05$ (RANOVA) between ATP control and $3 \mu \mathrm{mol} / \mathrm{l} \mathrm{PPADS} ;{ }^{\dagger} \mathrm{p}<0.05$ between 3 and 100 $\mu \mathrm{mol} / \mathrm{l}$ PPADS (RANOVA). 


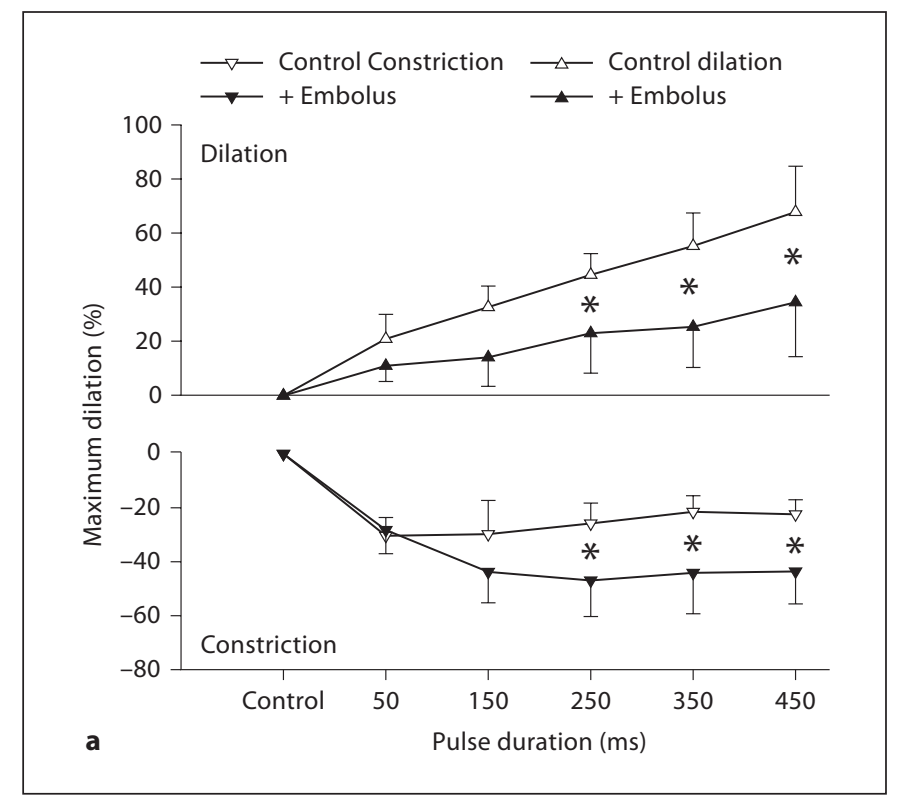

Fig. 4. Effect of air embolus on ATP-induced responses. Air embolization significantly enhances local initial constriction and reduces local dilation at high pulse durations (a) and reduces conducted dilation but not conducted constriction (b). These results indicate that the $\mathrm{P}_{2 \mathrm{X} 1}$ receptors causing transient constriction re-

tions [24]. Vessels used to test the effect of suramin had a maximum diameter of $68.3 \pm 5.6 \mu \mathrm{m}$ and a tone diameter of $48.0 \pm 3.8 \mu \mathrm{m}(\mathrm{n}=8)$. When we compared vessel dilations to extraluminal $100 \mu \mathrm{mol} / \mathrm{l}$ ATP before and after suramin $(1 \mu \mathrm{mol} / \mathrm{l})$, we found no difference in either the dilatory or constrictor responses. The higher concentrations of suramin needed to inhibit $\mathrm{P}_{2 \mathrm{Y} 2}$ receptors [24] induced complete vessel dilation within the incubation period of $20 \mathrm{~min}$ and could not be used. Similarly, the ecto-ATPase inhibitor Reactive Blue 2 [24], which was used on 7 additional vessels, again dilated the vessels at concentrations higher than $1 \mu \mathrm{mol} / \mathrm{l}$ (data not shown).

\section{Contribution of Endothelial Impairment and}

Endothelial Factors (NO, Prostanoids, EETs) to Local

and Conducted Vasomotor Responses

Vessels used with air embolization had a maximum diameter of $66.8 \pm 7.8 \mu \mathrm{m}$ and a tone diameter of 46.4 $\pm 8.8 \mu \mathrm{m}(\mathrm{n}=4)$. Air embolization significantly reduced the control diameter, indicating successful endothelial damage ( $46.4 \pm 8.8$ vs. $40.4 \pm 9.7 \mu \mathrm{m}, \mathrm{p}<0.05)$. ATPinduced local constriction was potentiated by the endothelial impairment and dilation was attenuated (fig. 4). The conducted dilation was also reduced after air embo-

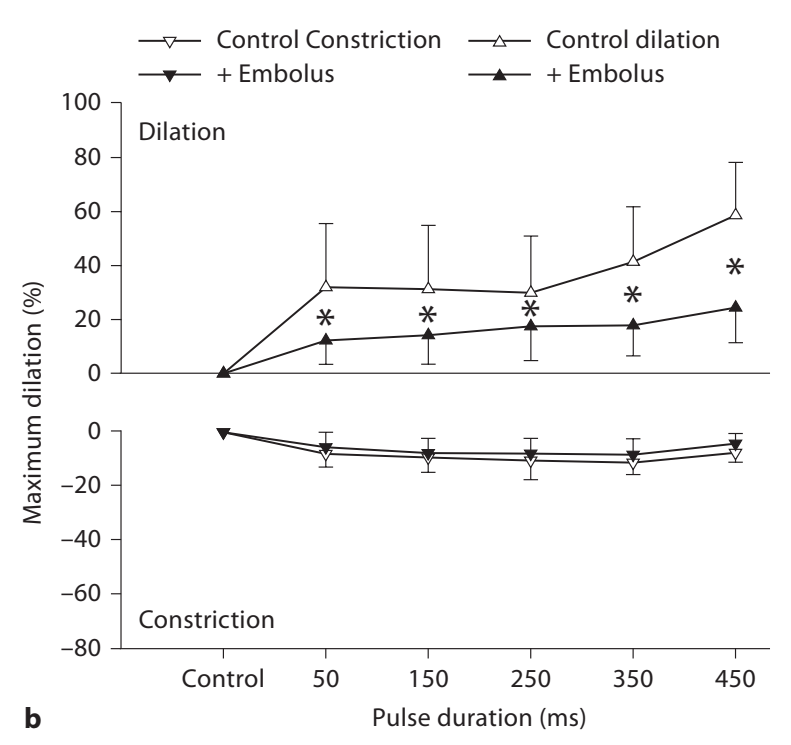

side on smooth-muscle cells and that the $\mathrm{P}_{2 \mathrm{Y} 2}$ receptors causing dilation are present on the endothelium. Data are presented as percentages of maximum diameter, to compensate for control diameter change induced by the embolism. $\mathrm{n}=4 .{ }^{*} \mathrm{p}<0.05$ (RANOVA) between control and after embolization.

lization, but the conducted constriction was unchanged (fig. 4).

Vessels exposed to L-NMMA had a maximum diameter of $48.2 \pm 6.8 \mu \mathrm{m}$ with a tone diameter of $30.7 \pm$ $3.5 \mu \mathrm{m}(\mathrm{n}=5)$. Inhibition of NOS with L-NMMA (10 $\mu \mathrm{mol} / \mathrm{l})$ constricted the vessels $(39.9 \pm 5.7$ vs. $33.5 \pm 6.0$ $\mu \mathrm{m}, \mathrm{p}<0.05)$ and partially affected the local dilation at low pulse durations (fig. 5). However, L-NMMA had no effect on the conduction (fig. 5).

Cyclooxygenase inhibition with indomethacin (10 $\mu \mathrm{mol} / \mathrm{l}$ ) influenced neither local nor conducted vasomotor responses (maximum vessel diameter $=51.6 \pm 2.9$ $\mu \mathrm{m}$, tone $=30.9 \pm 4.6 \mu \mathrm{m}, \mathrm{n}=4$, data not shown).

We used the specific cytochrome P450 inhibitor MS$\mathrm{PPOH}$ to inhibit the de novo production of EETs [19]. The vessels used in these studies had a maximum diameter of $67.0 \pm 0.6 \mu \mathrm{m}$ with a tone diameter of $52.0 \pm 2.5 \mu \mathrm{m}$. $1 \mu \mathrm{mol} / \mathrm{l} \mathrm{MS}-\mathrm{PPOH}$ did not affect the basal vessel diameter $(54.3 \pm 3.8 \mu \mathrm{m})$ but did significantly attenuate both local and conducted dilation, reducing the dilatory response for pulses from 250 to $450 \mathrm{~ms}(\mathrm{n}=4$; fig. 6). In preliminary experiments, we found that higher MS$\mathrm{PPOH}$ concentrations used in in vivo studies dilated our vessel preparation. 


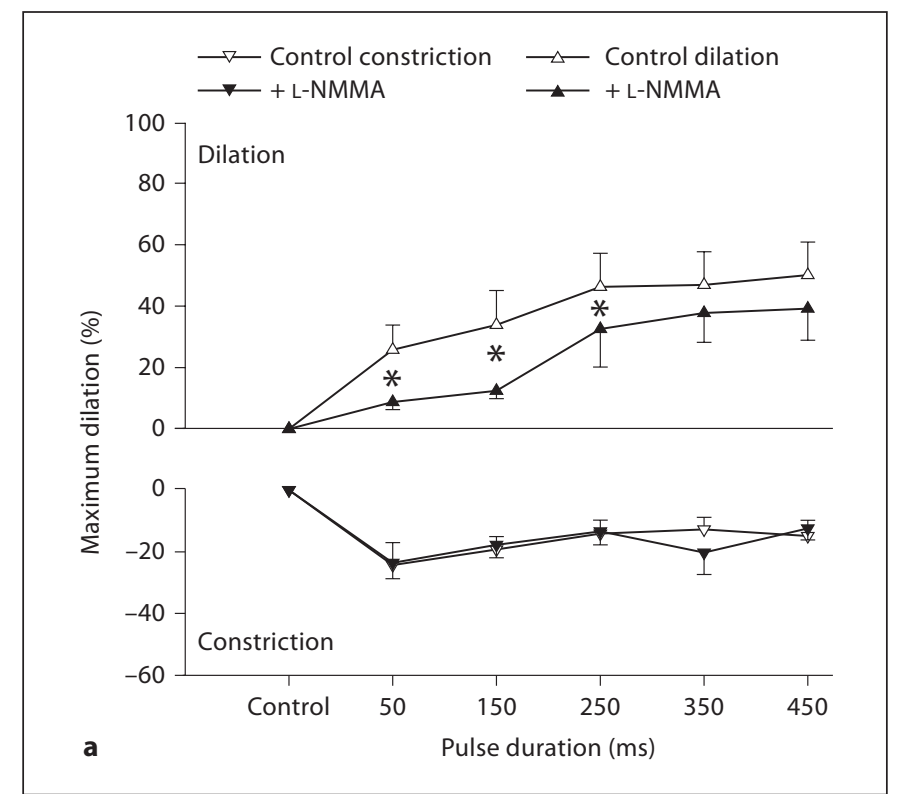

Fig. 5. Inhibition of NOS with L-NMMA $(10 \mu \mathrm{mol} / \mathrm{l})$ significantly reduces local dilation at low pulse durations (a), but not conducted (b) responses. This indicates that NO as an endothelial dilator is released at low ATP pulses, but that NO is not involved

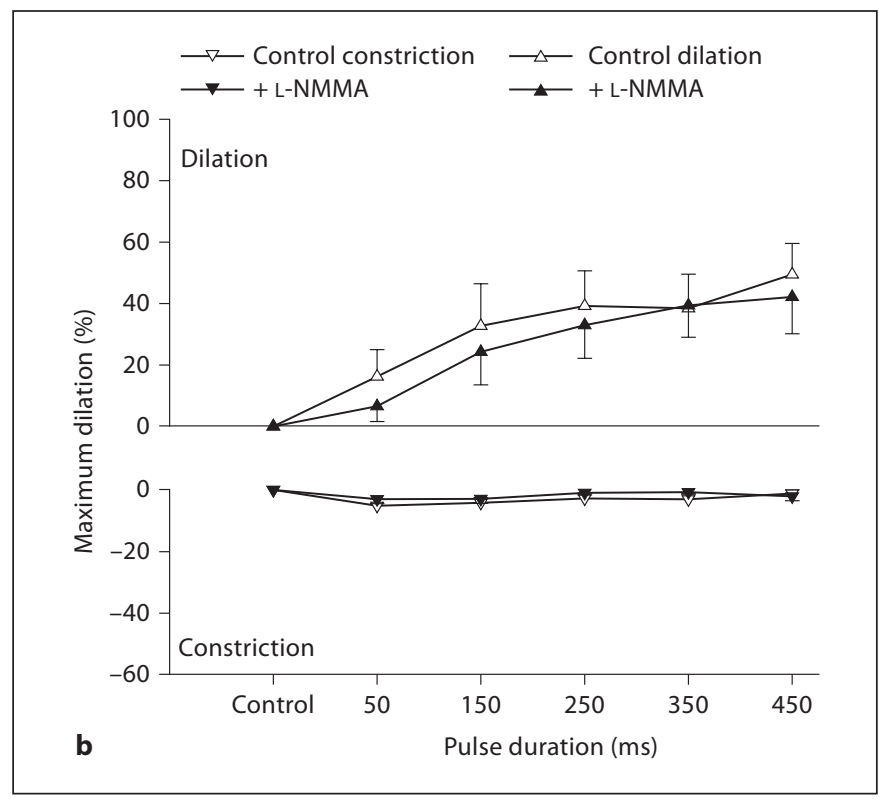

in the conducted vasomotor responses. Data are presented as percentage of maximum diameter, to compensate for control diameter change induced after NOS inhibition. $n=5 .{ }^{*} \mathrm{p}<0.05$ (RANOVA) between control and after L-NMMA.

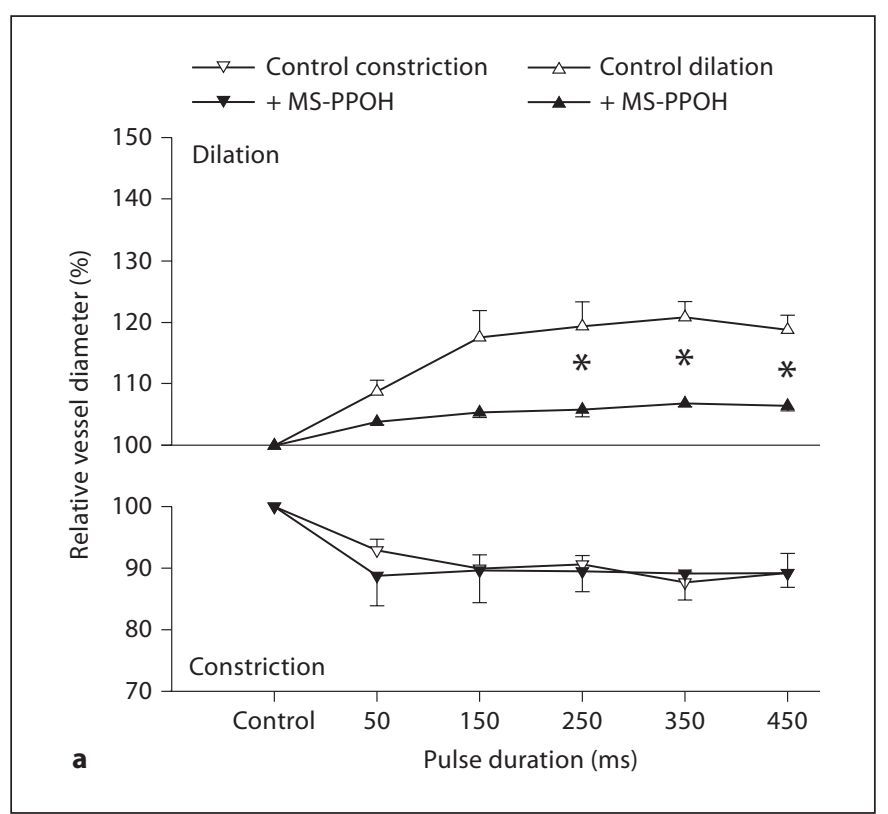

Fig. 6. Inhibiting the production of EETs with MS-PPOH ( $1 \mu \mathrm{mol} / \mathrm{l}$, cytochrome $\mathrm{P} 450$ inhibitor) significantly reduces local (a) and conducted (b) dilation. This indicates that a cytochrome $\mathrm{P} 450 \mathrm{EET}$ is released locally and that this product, possibly acting

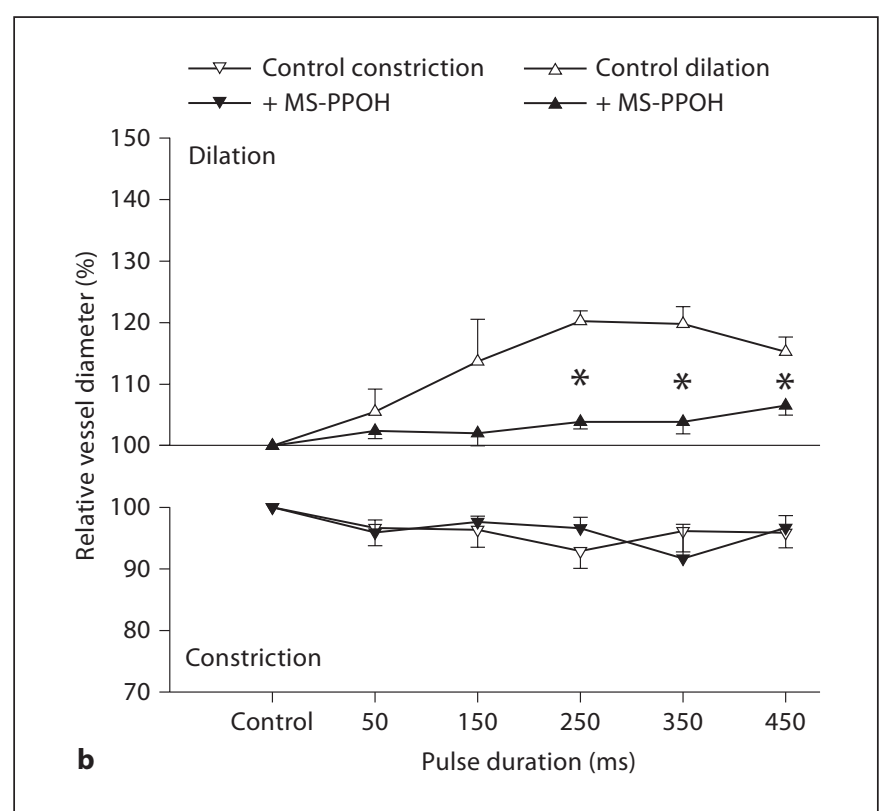

as an EDHF, contributes to the conducted vasomotor response. $\mathrm{n}=4 .{ }^{*} \mathrm{p}<0.05$ (RANOVA) between control and after MS$\mathrm{PPOH}$. 


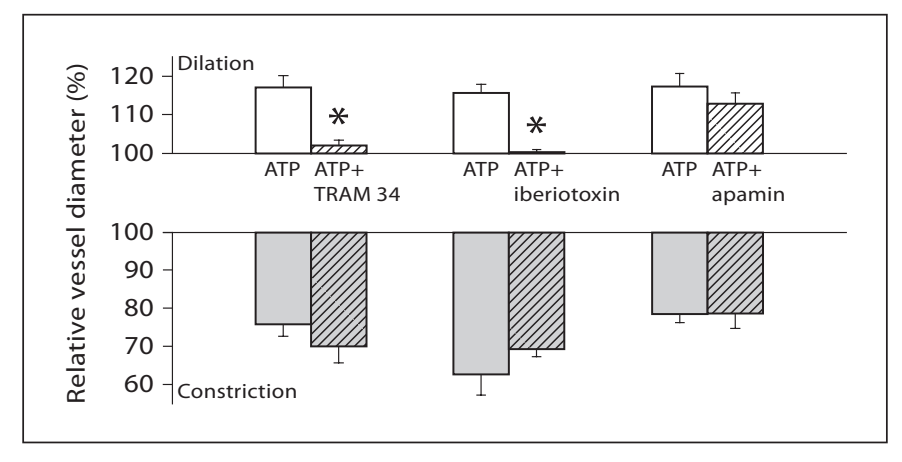

Fig. 7. Effect of calcium-sensitive potassium channel blocker on vasomotor responses to extraluminally applied ATP (100 $\mu \mathrm{mol} / \mathrm{l})$. Inhibition of $\mathrm{BK}_{\mathrm{Ca}}$ and $\mathrm{IK}_{\mathrm{Ca}}$, but not $\mathrm{SK}_{\mathrm{Ca}}$, inhibited the vessel dilation to $\mathrm{ATP}$, indicating that $\mathrm{BK}_{\mathrm{Ca}}$ and $\mathrm{IK}_{\mathrm{Ca}}$ activation dilates the penetrating arterioles.

\section{Calcium-Activated Potassium Channels and Extraluminally Applied ATP}

Since inhibition of cytochrome P450 resulted in reduced local and conducted vasomotor responses, EETs may contribute to ATP-induced dilation by activating calcium-sensitive potassium channels $\left(\mathrm{K}_{\mathrm{Ca}}\right)$ [25]. To elucidate the contribution of $\mathrm{K}_{\mathrm{Ca}}$ to the ATP-induced vasomotor responses, we applied ATP extraluminally in the absence or presence of specific $\mathrm{K}_{\mathrm{Ca}}$ channel inhibitors. Vessels exposed to TRAM-34 (a specific inhibitor of $\mathrm{IK}_{\mathrm{Ca}}$ channels) had a maximum diameter of $75.2 \pm 6.2 \mu \mathrm{m}$ with a tone diameter of $53.2 \pm 7.8 \mu \mathrm{m}(\mathrm{n}=4)$. Intraluminally applied TRAM-34 $(10 \mu \mathrm{mol} / \mathrm{l})$ did not affect basal tone diameter $(53.3 \pm 3.4 \mu \mathrm{m})$, but inhibited dilation to ATP (fig. 7). Extraluminally applied TRAM-34 had no effect (data not shown). Vessels exposed to iberiotoxin (a specific inhibitor of $\mathrm{BK}_{\mathrm{Ca}}$ channels) had a maximum diameter of $78.4 \pm 13.5 \mu \mathrm{m}$ with a tone diameter of $47.0 \pm$ $4.5 \mu \mathrm{m}(\mathrm{n}=4)$. Iberiotoxin did not affect the tone diameter $(47.3 \pm 7.0 \mu \mathrm{m})$, but inhibited dilation to ATP (fig. 7). Vessels treated with apamin had a maximum diameter of $79.8 \pm 5.7 \mu \mathrm{m}$, with a tone diameter of $52.8 \pm 4.8 \mu \mathrm{m}$ $(\mathrm{n}=4)$. Inhibition of $\mathrm{SK}_{\mathrm{Ca}}$ with $0.1 \mu \mathrm{mol} / \mathrm{l}$ apamin had no effect on the vessels' tone diameter $(52.8 \pm 4.8 \mu \mathrm{m}, \mathrm{n}=$ 4) or ATP-induced vasomotor responses (fig. 7).

\section{Discussion}

The major findings of this study were, first, that topically microapplied ATP consistently initiated conducted dilation, which was preceded by smooth-muscle hyper- polarization at the remote site in a stimulus-dependent manner. Second, endothelial impairment enhanced local but not conducted constriction and attenuated both local and conducted dilation. Third, microapplied ATP stimulated smooth-muscle $\mathrm{P}_{2 \mathrm{X} 1}$ receptors causing a transient constriction. Inhibition of $\mathrm{P}_{2 \times 1}$ receptors attenuated local and conducted constriction and enhanced local and conducted dilation. Local vessel dilation was mediated by endothelial $\mathrm{P}_{2 \mathrm{Y}}$ receptors, resulting in conducted dilation. Fourth, NO contributes to local dilation at low stimulation pulses but does not contribute to conducted dilation. Cytochrome P450 metabolites contribute to local dilation, and inhibition of cytochrome $\mathrm{P} 450$ greatly reduces both local and conducted dilation. Cyclooxygenase products are not involved in either local or conducted responses. Fifth, ATP-induced dilation involves activation of $\mathrm{IK}_{\mathrm{Ca}}$ and $\mathrm{BK}_{\mathrm{Ca}}$ channels, but not $\mathrm{SK}_{\mathrm{Ca}}$ channels.

\section{Local ATP-Induced Vasomotor Responses, Conducted Vasodilation and Membrane Potentials}

Microapplication of ATP caused a biphasic response locally with an initial transient constriction followed by a dilation. This corresponds to previous observations by us and others $[8,10,12]$, and is similar to the reaction to globally applied ATP [4]. In our preparation, microapplied adenosine triphosphate consistently resulted in conducted vasodilation (e.g. $20 \%$ at 450 -ms pulses; fig. 2), while the conducted constriction was $5 \%$ at a distance of $1,200 \mu \mathrm{m}$. This result indicates that in our preparation, dilation is more prominently conducted than constriction. Ngai et al. [10] observed a 5\% conducted dilation that was preceded by a $5 \%$ conducted constriction at a distance of $1,000 \mu \mathrm{m}$. In hamster cheek pouch arterioles, Duza and Sarelius [12] found that only dilation was conducted in response to local ATP. In the present study, we found that at the remote site, conducted vasodilation was preceded by a membrane hyperpolarization similar to that seen with local acetylcholine stimulation in hamster cheek pouch arterioles [15]. Dora et al. [15] also observed that local acetylcholine-induced dilation was preceded by hyperpolarization, indicating that a local membrane potential change is the generator for the observed vasomotor response and that it is this membrane potential change which is conducted, resulting in the change in vessel diameter via electromechanical coupling. We consistently observed smooth-muscle hyperpolarization preceding the vessel dilation, indicating that electromechanical coupling may also be responsible for the vessel diameter change in our preparation. The local membrane potential response to ATP has not yet been measured in penetrat- 
ing arterioles. We observed that ATP induced an initial small depolarization with a similarly small constriction, indicating that both membrane depolarization and vessel constriction can be conducted. However, these responses were significantly less pronounced compared with the hyperpolarization and subsequent dilation (fig. 1). The change in membrane hyperpolarization correlated well with vessel dilation. These findings indicate that in rat penetrating arterioles, the dilation at the remote site is conducted electrically along the arteriolar wall and is caused by hyperpolarization similar to other vessel preparations [15].

\section{ATP-Induced Vasomotor Responses and Purinergic Receptors}

Desensitization of $\mathrm{P}_{2 \mathrm{X} 1}$ receptors with $1 \mu \mathrm{mol} / \mathrm{l} \alpha, \beta$ MetATP or pretreatment with $3 \mu \mathrm{mol} / \mathrm{l}$ PPADS $\left(\mathrm{P}_{2 \mathrm{X} 1}\right.$ receptor antagonists at this concentration) diminished the local transient constriction while the subsequent dilation was potentiated. Endothelial denudation enhanced the ATP-induced vasoconstriction. These results indicate that ATP stimulates smooth-muscle $\mathrm{P}_{2 \mathrm{X} 1}$ receptors causing constriction [13]. Inhibition of smooth-muscle $\mathrm{P}_{2 \mathrm{X} 1}$ receptors enhanced conducted dilation, indicating that $\mathrm{P}_{2 \mathrm{X} 1}$ receptor stimulation competes with the dilatory response both locally and during conduction. We did not measure the smooth-muscle membrane potential at the local stimulation site due to strong vessel wall movement. However, we did observe small depolarizations and conducted constrictions at the distal site (fig. 1), indicating that membrane depolarization may have occurred locally and that this depolarization was conducted. $\mathrm{P}_{2 \mathrm{X}}$-receptor-induced depolarization and contraction was previously observed in vas deferens [26]. The mechanism by which $\mathrm{P}_{2 \mathrm{X} 1}$ stimulation causes depolarization in cerebral arterioles is not known.

Two endothelial $\mathrm{P}_{2}$ receptors, $\mathrm{P}_{2 \mathrm{Y} 1}$ and $\mathrm{P}_{2 \mathrm{Y} 2}$, are reported to cause dilation [27]. We recently reported that global ATP activated both endothelial $\mathrm{P}_{2 \mathrm{Y} 1}$ and $\mathrm{P}_{2 \mathrm{Y} 2}$ receptors. This conclusion was based on the observation that when the receptors were stimulated by receptor-specific agonists [13], $100 \mu \mathrm{mol} / \mathrm{l}$ PPADS inhibited $\mathrm{P}_{2 \mathrm{Y}}$, but not $\mathrm{P}_{2 \mathrm{Y} 2}$ receptor stimulation [4]. Inhibition of $\mathrm{P}_{2 \mathrm{X} 1}$ receptors with $3 \mu \mathrm{mol} / \mathrm{l}$ PPADS enhanced local dilation, indicating that endothelial $\mathrm{P}_{2 \mathrm{Y}}$ receptors are present [4]. However, we found no difference in ATP-induced local dilation in the presence of $100 \mu \mathrm{mol} / \mathrm{l}$ PPADS (an inhibitor of all $\mathrm{P}_{2 \mathrm{Y}}$ receptors except $\mathrm{P}_{2 \mathrm{Y} 2}$ ) [27]. These findings suggest that microapplied ATP produced dilation primarily via stimulation of the endothelial $\mathrm{P}_{2 \mathrm{Y}}$ receptor. We also observed no change in conducted vasodilation after the inhibition of $\mathrm{P}_{2 \mathrm{Y} 1}$ receptors with $100 \mu \mathrm{mol} / \mathrm{l}$ PPADS, indicating that local endothelial $\mathrm{P}_{2 \mathrm{Y}}$, possibly via $\mathrm{P}_{2 \mathrm{Y} 2}$ stimulation, is the generator for the conducted vasodilation. Suramin and Reactive Blue 2 inhibit $\mathrm{P}_{2 \mathrm{Y} 2}$ receptors at concentrations of $20 \mu \mathrm{mol} / \mathrm{l}$ and higher [24]. However, concentrations of these inhibitors greater than $1 \mu \mathrm{mol} / 1$ dilated our vessel preparation and could not be used. In the hamster cheek pouch, Duza and Sarelius [12] reported that conducted vasomotor responses to locally applied ATP and adenosine depend on endothelial $\mathrm{P}_{1}$ receptors, with ATP being hydrolyzed to adenosine [24]. Rat penetrating arterioles, which have adenosine receptors present on the smooth muscle but not the endothelium [22, 23], strongly dilated to locally applied adenosine but did not show conduction [8]. We used a low concentration of suramin to reduce hydrolysis of ATP by ecto-ATPases [24] and found no change in vessel dilation to extraluminally applied ATP. This suggests that in rat penetrating arterioles, ATP hydrolysis with subsequent adenosine receptor stimulation was not causing the observed dilation. Due to the dilatory effect of the higher concentration of suramin (or Reactive Blue 2), we were unable to determine directly if $\mathrm{P}_{2 \mathrm{Y} 2}$ receptor stimulation is responsible for the observed local ATP response. Future experiments with specific $\mathrm{P}_{2 \mathrm{Y} 1}$ and $\mathrm{P}_{2 \mathrm{Y} 2}$ agonists should help to elucidate which receptor is involved in the local and conducted vasomotor responses to ATP [13].

Our results show that inhibiting the smooth-muscle $\mathrm{P}_{2 \mathrm{X} 1}$ receptor enhanced the local endothelial $\mathrm{P}_{2 \mathrm{Y}}$-receptor-dependent dilation and the conducted dilation. This seems to indicate that the $\mathrm{P}_{2 \mathrm{X} 1}$ receptor response counteracts the $\mathrm{P}_{2 \mathrm{Y}}$-induced hyperpolarization and dilation, since the conducted dilation is also enhanced. Further, only local responses that cause a change in the membrane potential contribute to conducted responses, as indicated by others [15].

\section{Contribution of NO, Prostanoids and EDHF}

Endothelial $\mathrm{P}_{2 \mathrm{Y}}$ activation releases $\mathrm{NO}$, prostanoids or EDHF, depending on the species and $\mathrm{P}_{2 \mathrm{Y}}$ receptor type studied [27]. Inhibition of cyclooxygenase had no effect on ATP-induced local or conducted vasomotor responses in our preparation. The finding that prostanoids may not be involved is similar to our previous findings [13] and those of others in the cerebral circulation [28]. Inhibition of NOS decreased dilation only at short pulse durations. This corresponds with our previous study, where NOS inhibition only affected ATP induced dilation at low agonist concentrations [13], which was similar to response in 
larger cerebral vessels [28]. We previously found that specific $\mathrm{P}_{2 \mathrm{Y} 1}$ receptor stimulation releases both $\mathrm{NO}$ (at low agonist concentrations) and an EDHF at higher concentration, while $\mathrm{P}_{2 \mathrm{Y} 2}$ stimulation releases only an EDHF [13]. Inhibition of NOS had no effect on conducted vasomotor responses, indicating that $\mathrm{NO}$ does not contribute to the generation of the conducted response or conduction itself, possibly because NO does not affect the arteriolar membrane potential as an EDHF would do. The effect of NOS inhibition on the membrane potential has not been measured in our preparation. Hoepfl et al. [14] observed that in hamster cremaster arterioles, NO is not critical for acetylcholine-induced conducted vasodilation. However, Collins et al. [29] reported that in hamster retractor muscle, inhibition of NOS did eliminate retrograde conducted vasodilation to intravenular ATP.

To test for the contribution of EDHFs, we applied the specific cytochrome $\mathrm{P} 450$ inhibitor MS-PPOH, which strongly attenuated both local and conducted ATP-induced dilation, indicating that de novo synthesized EETs may be involved in the dilatory response [30]. These findings are similar to those of Hoepfl et al. [14], who found that cytochrome $\mathrm{P} 450$ inhibition with 17-octadecynoic acid reduced local and conducted vasomotor responses to acetylcholine in hamster cremaster arterioles.

\section{Calcium-Sensitive Potassium Channels and \\ ATP-Induced Vasomotor Responses}

EETs can cause dilation through activation of calcium-sensitive potassium channels and subsequent membrane hyperpolarization [16]. Since it is not known if ATP activates calcium-sensitive potassium channels in rat penetrating arterioles, we sought to elucidate the contribution of these channels to vasomotor responses to extraluminally applied ATP. We used specific inhibitors of these channels. We found that $\mathrm{BK}_{\mathrm{Ca}}$ and $\mathrm{IK}_{\mathrm{Ca}}$, but not $\mathrm{SK}_{\mathrm{Ca}}$, channels contribute to ATP-induced dilation. Activation of $\mathrm{K}_{\mathrm{Ca}}$ channels causes hyperpolarization, contributing to the local dilation [31]. These results indicate that EETs generated by cytochrome P450 may contribute to ATP-induced local dilation, possibly by activating potassium channels [16].

Taken together, these results suggest that microapplied ATP may locally release endothelial NO (at low stimulation pulses) and cytochrome P450 metabolites ( $\mathrm{P}_{2 \mathrm{Y}}$ stimulation) causing dilation. Since EETs produced by cytochrome $\mathrm{P} 450$ can activate potassium channels [16], ATP may, in part, dilate penetrating arterioles by activating $\mathrm{IK}_{\mathrm{Ca}}$ and $\mathrm{BK}_{\mathrm{Ca}}$ channels to initiate the conducted response.

\section{Local Stimulation and Extraluminal Antagonists}

In the present studies, we employed microapplication to cause a local vasomotor response and we applied inhibitors extraluminally. Thus, after inhibition, the changed vasomotor responses at the local site reflected the contribution of the inhibited mechanisms (e.g. NO or EDHF) on the local vessel response. Since we applied inhibitors globally, it is possible that the inhibitors not only affected the local vasomotor response, but also the conduction along the vessel and/or the remote vasomotor response. Thus, future experiments with focal application of inhibitors (e.g. inhibitor only at the local or the remote site) have to be done to distinguish which mechanisms are involved in the local and/or remote vasomotor responses.

\section{Pathology and Conducted Vasodilation in Cerebral Arterioles}

In these studies, damage to the endothelium induced by air embolization resulted in constriction of the penetrating arterioles, which effectively raises microvascular resistance. In addition, we observed that the local constriction was enhanced and local and conducted vasodilation to ATP was attenuated. Air embolization of microvessels damages the endothelial function, but does not remove the endothelial cells $[4,32]$. It is therefore possible that the residual endothelial cell layer still provided a conduit to allow conducted responses [4].

Conducted vasodilation is a prerequisite to allow an increase in microvascular flow in response to local metabolic demand [7]. Thus, impairment of endothelial function and the subsequent reduction in conducted vasodilation in penetrating arterioles may further decrease cerebral microvascular blood flow. The reduction in conducted dilation is similar to the effect of oxyhemoglobin [9].

\section{Interplay of Local Endothelial and Smooth-Muscle \\ Factors Resulting in Local and Conducted Vasomotor \\ Responses}

Our results indicate that ATP locally stimulates smooth-muscle $\mathrm{P}_{2 \mathrm{X} 1}$ receptors, causing local constriction and some conducted depolarization or constriction (fig. 1d, 2, 3). This indicates that $\mathrm{P}_{2 \times 1}$-induced constriction may involve a local depolarization. We found that ATP stimulates $\mathrm{P}_{2 \mathrm{Y} 1}$ and $\mathrm{P}_{2 \mathrm{Y} 2}$ receptors, where $\mathrm{P}_{2 \mathrm{Y} 1}$ stimulation appears to liberate $\mathrm{NO}$ and a non-NO- and noncyclooxygenase-dependent factor, possibly an EDHF dependent on cytochrome $\mathrm{P} 450$ [13], and $\mathrm{P}_{2 \mathrm{Y} 2}$ liberates only a non-NO- and non-cyclooxygenase-dependent factor 
(i.e. EDHF) [13]. As such, both $\mathrm{NO}$ and an EDHF may contribute to the local dilation. For a local response to lead to a conducted one, most studies indicate that a local membrane potential change has to occur [15]. However, inhibition of NO did not result in a decreased conducted dilation. Thus, it appears that only the EDHF component contributes to a local membrane potential change leading to conduction, but NO causes local dilation without hyperpolarization. Therefore, while inhibition of NO decreased the local dilation, the EDHF component was unaltered and the conducted response unchanged. Inhibition of either NO or EDHF resulted in a decreased local dilatory response, but not enhanced constriction. It is possible that the presence of the noninhibited dilator (either NO or EDHF) was sufficient to prevent an increased constriction. This is supported by the observation that air embolus-induced endothelial damage caused increased smooth-muscle constriction to ATP. Our data therefore shows an intricate interplay among the various factors invoked by ATP stimulation on both local and conducted responses.

In summary, in rat cerebral arterioles in vitro, microapplication of ATP produces a biphasic response resulting in a transient constriction via smooth-muscle $\mathrm{P}_{2 \mathrm{X} 1}$ receptors and subsequent dilation, primarily due to endothelial $\mathrm{P}_{2 \mathrm{Y}}$ receptor activation. Conducted vasomotor responses travel along the vessel with a membrane hyperpolarization that precedes vessel dilation. ATP produces NO and cytochrome P450 metabolites (EETs) which locally dilate the vessel, but NO does not contribute to conduction. Activation of $\mathrm{IK}_{\mathrm{Ca}}$ and $\mathrm{BK}_{\mathrm{Ca}}$, but not $\mathrm{SK}_{\mathrm{Ca}}$, channels may contribute to ATP-induced dilation.

\section{Acknowledgments}

This work was supported by National Institutes of Health grants HL57540 (to H.H.D.), P01 NS32636 (to H.H.D.), NS30555 (to R.G.D. and H.H.D.) and GM31278 (to J.R.F.).

\section{References}

1 Rosenblum WI, Kontos HA: The importance and relevance of studies of the pial microcirculation. Stroke 1974;5:425-428.

- 2 Filosa JA, Bonev AD, Nelson MT: Calcium dynamics in cortical astrocytes and arterioles during neurovascular coupling. Circ Res 2004;95:e73-e81.

- 3 You JP, Johnson TD, Marrelli SP, Mombouli JV, Bryan RM Jr: $\mathrm{P}_{2 \mathrm{u}}$ receptor-mediated release of endothelium-derived relaxing factor nitric oxide and endothelium-derived hyperpolarizing factor from cerebrovascular endothelium in rats. Stroke 1999;30:11251132 .

-4 Horiuchi T, Dietrich HH, Tsugane S, Dacey RG Jr: Analysis of purine- and pyrimidineinduced vascular responses in the isolated rat cerebral arteriole. Am J Physiol Heart Circ Physiol 2001;280:H767-H776.

5 You J, Golding EM, Bryan RM Jr: Arachidonic acid metabolites, hydrogen peroxide, and EDHF in cerebral arteries. Am J Physiol Heart Circ Physiol 2005;289:H1077-H1083.

-6 Saino T, Matsuura M, Satoh YI: Comparison of the effect of ATP on intracellular calcium ion dynamics between rat testicular and cerebral arteriole smooth muscle cells. Cell Calcium 2002;32:153-163.

7 Kurjiaka DT, Segal SS: Conducted vasodilation elevates flow in arteriole networks of hamster striated muscle. Am J Physiol 1995; 269:H1723-H1728.
8 Dietrich HH, Kajita Y, Dacey RG Jr: Local and conducted vasomotor responses in isolated rat cerebral arterioles. Am J Physiol Heart Circ Physiol 1996;271:H1109-H1116.

-9 Kajita Y, Dietrich HH, Dacey RG Jr: Effects of oxyhemoglobin on local and propagated vasodilatory responses induced by adenosine, adenosine diphosphate, and adenosine triphosphate in rat cerebral arterioles. J Neurosurg 1996;85:908-916.

10 Ngai AC, Nguyen TS, Meno JR, Britz GW: Postischemic augmentation of conducted dilation in cerebral arterioles. Stroke 2007;38: 124-130.

11 McCullough WT, Collins DM, Ellsworth ML: Arteriolar responses to extracellular ATP in striated muscle. Am J Physiol 1997; 272:H1886-H1891.

12 Duza T, Sarelius IH: Conducted dilations initiated by purines in arterioles are endothelium dependent and require endothelial $\mathrm{Ca}^{2+}$. Am J Physiol Heart Circ Physiol 2003; 285: $\mathrm{H} 26-\mathrm{H} 37$.

$\checkmark 13$ Horiuchi T, Dietrich HH, Hongo K, Dacey RG Jr: Comparison of $\mathrm{P}_{2}$ receptor subtypes producing dilation in rat intracerebral arterioles. Stroke 2003;34:1473-1478.

14 Hoepfl B, Rodenwaldt B, Pohl U, de Wit C: EDHF, but not NO or prostaglandins, is critical to evoke a conducted dilation upon ACh in hamster arterioles. Am J Physiol Heart Circ Physiol 2002;283:H996-H1004.
15 Dora KA, Xia J, Duling BR: Endothelial cell signaling during conducted vasomotor responses. Am J Physiol Heart Circ Physiol 2003:285:H119-H126.

16 Alkayed NJ, Narayanan J, Gebremedhin D, Medhora M, Roman RJ, Harder DR: Molecular characterization of an arachidonic acid epoxygenase in rat brain astrocytes. Stroke 1996;27:971-979.

-17 Dietrich HH, Dacey RG Jr: Effects of extravascular acidification and extravascular alkalinization on constriction and depolarization in rat cerebral arterioles in vitro. J Neurosurg 1994;81:437-442.

18 Ralevic V, Burnstock G: Discrimination by PPADS between endothelial $\mathrm{P}_{2 \mathrm{Y}^{-}}$and $\mathrm{P}_{2 \mathrm{U}^{-}}$ purinoceptors in the rat isolated mesenteric arterial bed. Br J Pharmacol 1996;118:428434.

19 Wang MH, Brand-Schieber E, Zand BA, Nguyen X, Falck JR, Balu N, Schwartzman ML: Cytochrome P450-derived arachidonic acid metabolism in the rat kidney: characterization of selective inhibitors. J Pharmacol Exp Ther 1998;284:966-973.

-20 Marrelli SP, Eckmann MS, Hunte MS: Role of endothelial intermediate conductance $\mathrm{K}_{\mathrm{Ca}}$ channels in cerebral EDHF-mediated dilations. Am J Physiol Heart Circ Physiol 2003; 285:H1590-H1599.

21 Faraci FM, Lynch C, Lamping KG: Responses of cerebral arterioles to ADP: eNOS-dependent and eNOS-independent mechanisms. Am J Physiol Heart Circ Physiol 2004; 287:H2871-H2876. 
-22 Ngai AC, Coyne EF, Meno JR, West GA, Winn HR: Receptor subtypes mediating adenosine-induced dilation of cerebral arterioles. Am J Physiol Heart Circ Physiol 2001; 280:H2329-H2335.

-23 Ngai AC, Winn HR: Effects of adenosine and its analogues on isolated intracerebral arterioles: extraluminal and intraluminal application. Circ Res 1993;73:448-457.

24 Chen BC, Lee CM, Lin WW: Inhibition of ecto-ATPase by PPADS, suramin and reactive blue in endothelial cells, $\mathrm{C}_{6}$ glioma cells and RAW 264.7 macrophages. Br J Pharmacol 1996;119:1628-1634.
5 Alkayed NJ, Birks EK, Hudetz AG, Roman RJ, Henderson L, Harder DR: Inhibition of brain P-450 arachidonic acid epoxygenase decreases baseline cerebral blood flow. Am J Physiol Heart Circ Physiol 1996;271:H1541H1546.

26 Kennedy C: ATP as a cotransmitter in perivascular sympathetic nerves. J Auton Pharmacol 1996;16:337-340.

27 Ralevic V, Burnstock G: Receptors for purines and pyrimidines. Pharmacol Rev 1998; 50:413-492.

-28 You JP, Johnson TD, Childres WF, Bryan RM Jr: Endothelial-mediated dilations of rat middle cerebral arteries by ATP and ADP. Am J Physiol Heart Circ Physiol 1997;273: H1472-H1477.
29 Collins DM, McCullough WT, Ellsworth ML: Conducted vascular responses: communication across the capillary bed. Microvasc Res 1998;56:43-53.

30 Lovick TA, Brown LA, Key BJ: Neuronal activity-related coupling in cortical arterioles: involvement of astrocyte-derived factors. Exp Physiol 2005;90:131-140.

$>31$ Nilius B, Droogmans G: Ion channels and their functional role in vascular endothelium. Physiol Rev 2001;81:1415-1459.

32 Saito Y, Eraslan A, Lockard V, Hester RL: Role of venular endothelium in control of arteriolar diameter during functional hyperemia. Am J Physiol Heart Circ Physiol 1994; 267:H1227-H1231. 